\title{
P01.39. Synergism of herbs in classical Chinese medicine: evidence from HPLC
}

\author{
K Shaw*, K Wright, J Wang, P Kalnins \\ From International Research Congress on Integrative Medicine and Health 2012 \\ Portland, Oregon, USA. 15-18 May 2012
}

\section{Purpose}

Classical Chinese herbal therapy uses herb combinations within formulas based upon the belief that there is a synergistic effect between herbs. Herbal pairs and combinations may change the hydrophobicity and ion concentration of the decoction. These changes may increase extraction of constituents from other herbs within the formula. Furthermore, herbs may react within the decoction medium to create new chemical structures. The purpose of this study is to compare chemical signatures of individual Chinese herbs with paired herbal formulas, as they are used in Classical Chinese medicine.

\section{Methods}

This study investigates the synergism of licorice with two herbs (Bupleurum chinense and Zingiberis officinalis) commonly used in Classical Chinese Medicine. Each sample was decocted in de-ionized water for one hour at $100{ }^{\circ} \mathrm{C}$. Individual and paired decoctions were analyzed using High Performance Liquid Chromatography (HPLC) to evaluate differences in chemical signatures between extractions.

\section{Results}

Chemical constituent concentration varied between single herb and paired herb decoctions. In the paired decoctions, many chemical peaks increased in concentration. Interestingly, other peaks decreased in concentration, though none disappeared.

\section{Conclusion}

This preliminary data demonstrate that paired herbal decoctions contain increased levels of active components. Furthermore, a decrease in peaks within the paired decoction but not in the individual formulas

National College of Natural Medicine, Portland, USA suggests that herb decoctions generated new chemical structures. This study represents foundational research into synergistic relationships between herbs.

Published: 12 June 2012

doi:10.1186/1472-6882-12-S1-P39

Cite this article as: Shaw et al:: P01.39. Synergism of herbs in classical

Chinese medicine: evidence from HPLC. BMC Complementary and

Alternative Medicine 2012 12(Suppl 1):P39.
Submit your next manuscript to BioMed Central and take full advantage of:

- Convenient online submission

- Thorough peer review

- No space constraints or color figure charges

- Immediate publication on acceptance

- Inclusion in PubMed, CAS, Scopus and Google Scholar

- Research which is freely available for redistribution

Submit your manuscript at www.biomedcentral.com/submit
( Bīomed Central

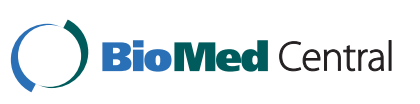

(c) 2012 Shaw et al; licensee BioMed Central Ltd. This is an Open Access article distributed under the terms of the Creative Commons Attribution License (http://creativecommons.org/licenses/by/2.0), which permits unrestricted use, distribution, and reproduction in any medium, provided the original work is properly cited. 